University of Nebraska - Lincoln

DigitalCommons@University of Nebraska - Lincoln

1973

\title{
Chronic Toxicity of a Copper, Cadmium and Zinc Mixture to the Fathead Minnow (Pimephales Promelas Rafinesque)
}

John G. Eaton

United States Environmental Protection Agency

Follow this and additional works at: https://digitalcommons.unl.edu/usepapapers

Part of the Civil and Environmental Engineering Commons

Eaton, John G., "Chronic Toxicity of a Copper, Cadmium and Zinc Mixture to the Fathead Minnow (Pimephales Promelas Rafinesque)" (1973). U.S. Environmental Protection Agency Papers. 3. https://digitalcommons.unl.edu/usepapapers/3

This Article is brought to you for free and open access by the U.S. Environmental Protection Agency at DigitalCommons@University of Nebraska - Lincoln. It has been accepted for inclusion in U.S. Environmental Protection Agency Papers by an authorized administrator of DigitalCommons@University of Nebraska - Lincoln. 


\title{
CHRONIC TOXICITY OF A COPPER, CADMIUM AND ZINC MIXTURE TO THE FATHEAD MINNOW (PIMEPHALES PROMELAS RAFINESQUE)
}

\author{
JOHN G. EATON \\ United States Environmental Protection Agency, National Water Quality Laboratory, \\ Duluth, Minnesota 55804, U.S.A.
}

(Received 1 January 1973)

\begin{abstract}
Fathead minnows were exposed to a series or concentrations of a copper, cadmium and zinc mixture during a 12.5 month chronic test in water of $200 \mathrm{mg} \mathrm{l}^{-1}$ total hardness. The metal concentrations in the mixture were selected on the basis of results obtained during previous chronic exposures to each of the metals individually in the same water. Strict summation of the chronic toxicities of the metals was not indicated when they were tested in combination. Toxic effects of the mixture attributable to copper appeared to be increased, but that attributable to cadmium was reduced. The effects thought to be due to zinc were similar in degree to those observed in the single chronic exposure. Summation of effects resulting from a mixture containing about the same proportions of copper, cadmium and zinc occurred at a much higher, acutely lethal concentration. A lethal threshold was attained in the mixture when each metal was present at a concentration of 0.4 or less of its individual lethal threshold.
\end{abstract}

\section{INTRODUCTION}

IN MOST situations where pollutants are being introduced into natural waters, more than one toxic or potentially toxic substance is present. The larger the body of water, the more likely it is that mixtures of pollutants will be present. Only limited information is available, however, regarding similarities or differences between the effects attributable to single pollutants and the effects when these pollutants are combined. Most laboratory studies of the effects of toxicants on fish have involved exposures to only one toxicant at a time. Some acute toxicity studies on mixtures have been reported, mostly by British investigators (LLOYD, 1961; HeRBERT and SHURBEN, 1964; Herbert and VAN DYke, 1964; Brown, 1968; Brown and Dalton, 1970; and others), but no information is available on the chronic toxicity of mixtures.

The present study was undertaken to explore the joint toxicity of three heavy metals. Their individual chronic toxicities have previously been observed at the Newtown Fish Toxicology Laboratory. Using the same source of test fish and the identical water supply that were used in the work reported here, MounT (1968) had determined the chronic toxicity of copper to the fathead minnow, BRUNGS (1969) the chronic toxicity of zinc, and PICKERING and GAST (1972) the chronic toxicity of cadmium. Since chronically determined safe concentrations for chronic exposures, derived from such individual-toxicant bioassays, are currently being translated into water-quality standards, a need was felt to examine the chronic toxicity of a mixture of these toxicants. The bioassays described here were conducted at the National Water Quality Laboratory, Newtown Fish Toxicology Laboratory Field Station, Newtown, Ohio. 


\section{MATERIALS AND METHODS}

The test water consisted of a mixture of Newtown Fish Farm (Ohio Division of Wildlife) spring water and carbon-filtered, demineralized Cincinnati tap water. Total hardness was maintained at close to $200 \mathrm{mg}^{-1}$ (as $\mathrm{CaCO}_{3}$ ). After mixing, the water was temporarily stored in a 400,000 1. outdoor reservoir, from which it flowed by gravity into the laboratory. Upon entering the laboratory, test water passed through a constant level-regulating headbox, in which a temperature regulating device was located, and on to a proportional-dilution apparatus (MounT and BRUNGS, 1967). This "diluter" controlled the intermittent delivery of five toxicant-bearing water streams and a control water stream at a flow rate of 0.51 . to each tank every $3 \mathrm{~min}$ throughout the test period. This flow rate was sufficient to provide an amount of water equal to the tank volume in $6 \mathrm{~h}$, or a 95 per cent replacement every $18 \mathrm{~h}$. The toxicant metering portion of the diluter was checked at least once every day to see that it was delivering the correct amount of metal stock solution. In addition, the diluter was thoroughly cleaned once during the exposure period, and the amounts of test water siphoned from the various diluter cells were checked twice.

Values obtained during the routine analysis of the test water are presented in TABLE 1. No differences between tanks in these chemical characteristics could be

TABle 1. Chemical characteristics of test Water-Means AND Ranges

\begin{tabular}{lccc}
\hline \multicolumn{1}{c}{ Characteristic } & $\begin{array}{c}\text { Number } \\
\text { of analyses }\end{array}$ & $\begin{array}{c}\text { Arithmetic } \\
\text { mean }\end{array}$ & Range \\
\hline Acidity $\left(\mathrm{mg} \mathrm{l}^{-1}\right.$ as $\left.\mathrm{CaCO}_{3}\right)$ & 118 & 10.5 & $6.0-18.0$ \\
Alkalinity $\left(\mathrm{mg} \mathrm{1}^{-1}\right.$ as $\left.\mathrm{CaCO}_{3}\right)$ & 118 & 154 & $136-180$ \\
Total hardness $\left(\mathrm{mg} \mathrm{1}^{-1}\right.$ as $\left.\mathrm{CaCO}_{3}\right)$ & 120 & 207 & $191-224$ \\
Specific conducitvity $(\mu ⿰)$ & 115 & 454 & $380-492$ \\
pH & 118 & 7.70 & $7.35-7.90$ \\
Dissolved oxygen $\left(\mathrm{mg} \mathrm{l}^{-1}\right)$ & 354 & 6.6 & $3.8-8.7$ \\
\hline
\end{tabular}

attributed to the different toxicant concentrations. Additional constituents of the water used in these tests have been reported elsewhere (MOUNT, 1968; BRUNGS, 1969). Two dissolved oxygen values of $3.8 \mathrm{mg}^{-1}$ were recorded, both of them in the control tank. The rest were above $4 \mathrm{mg}^{-1}$ and all but 16 of these were $5 \mathrm{mg} \mathrm{l}^{-1}$ or higher.

Stock solutions were prepared by dissolving reagent grade $\mathrm{CuSO}_{4} \cdot 5 \mathrm{H}_{2} \mathrm{O}$, $3 \mathrm{CdSO}_{4} \cdot 8 \mathrm{H}_{2} \mathrm{O}$ and $\mathrm{ZnSO}_{4} \cdot 7 \mathrm{H}_{2} \mathrm{O}$ in acidified demineralized water. "Super" stocks were used in preparing the less concentrated diluter stock solutions, about $2 \mathrm{ml}$ of which were metered into the diluent water with each diluter cycle. Appropriate amounts of the metal salts were used so that $30 \mu \mathrm{g} \mathrm{1^{-1 }}$ of copper, $60 \mu \mathrm{g} \mathrm{1^{-1 }}$ of cadmium and $300 \mu \mathrm{g}^{-1}$ of zinc were metered into the diluent water of the experimental tank containing the highest concentrations. The concentrations going to the four remaining experimental tanks were diluted successively by 50 per cent so that approximately $1.9 \mu \mathrm{g}^{-1}$ of copper, $3.7 \mu \mathrm{g}^{-1}$ of cadmium and $19 \mu \mathrm{g}^{-1}$ of zinc were added to the lowest concentration test water. In addition, small amounts of these metals were inherently present in the control-tank water. These metal ranges were selected because it had been demonstrated previously through chronic tests that when tested singly 
the highest concentrations were toxic to fathead minnows and the lowest concentrations were probably "safe".

The results of the chronic bioassay toxicant analyses are given in TABLE 2. Substantial proportions of the copper and zinc measured in the lower concentration tanks were contributed by the diluent (control) water.

Five-hundred-milliliter composite samples were collected from each tank for toxicant analysis by dipping out $100 \mathrm{ml}$ every weekday and acidified with 5 drops of concentrated sulfuric acid. To measure copper and cadmium a $400-\mathrm{ml}$ aliquot from each composite was extracted three times in a separatory funnel with $25 \mathrm{ml}$ of 0.1 per cent diethylammonium diethyldithiocarbamate in chloroform (after STARY, 1964). The chloroform was then evaporated on a water bath, the residue ashed with concentrated nitric acid and 25 per cent concentrated hydrochloric acid, and redissolved

TABle 2. CONCENTRATIONS OF COPPER, CADMIUM AND ZINC MIXTURES USED IN THE CHRONIC BIOASSAY

\begin{tabular}{|c|c|c|c|c|c|}
\hline \multirow[b]{2}{*}{$\begin{array}{c}\text { Chamber } \\
\text { number }\end{array}$} & \multirow{2}{*}{$\begin{array}{c}\text { Nominal } \\
\text { concentration } \\
\left(\mu \mathrm{g}^{-1}\right)\end{array}$} & \multirow{2}{*}{$\begin{array}{l}\text { Number } \\
\text { of } \\
\text { analyses }\end{array}$} & \multicolumn{3}{|c|}{ Measured concentration $\left(\mu \mathrm{g}^{-1}\right)$} \\
\hline & & & Mean & Range & $\begin{array}{l}\text { Standard } \\
\text { deviation }\end{array}$ \\
\hline $\begin{array}{c}1 \\
\text { (control) }\end{array}$ & $\begin{array}{ll}0 & \mathrm{Cu} \\
0 & \mathrm{Cd} \\
0 & \mathrm{Zn}\end{array}$ & $\begin{array}{l}56 \\
52 \\
50\end{array}$ & $\begin{array}{r}3.7 \\
0.6 \\
13.1\end{array}$ & $\begin{array}{l}1.9-5.5 \\
0.3-1.9 \\
7.0-24.0\end{array}$ & $\begin{array}{l}1.4 \\
0.5 \\
5.6\end{array}$ \\
\hline 2 & $\begin{array}{l}1.9 \mathrm{Cu} \\
3.8 \mathrm{Cd} \\
19 \mathrm{Zn}\end{array}$ & $\begin{array}{l}54 \\
58 \\
58\end{array}$ & $\begin{array}{r}5.3 \\
3.9 \\
27.3\end{array}$ & $\begin{array}{c}2.5-7.9 \\
2.2-5.5 \\
15.0-42.0\end{array}$ & $\begin{array}{l}1.5 \\
0.9 \\
7.9\end{array}$ \\
\hline 3 & $\begin{array}{l}3.8 \mathrm{Cu} \\
7.5 \mathrm{Cd} \\
38 \quad \mathrm{Zn}\end{array}$ & $\begin{array}{l}56 \\
58 \\
58\end{array}$ & $\begin{array}{r}6.7 \\
7.1 \\
42.3\end{array}$ & $\begin{array}{c}4.8-9.3 \\
4.0-10.0 \\
25.2-61.1\end{array}$ & $\begin{array}{l}1.3 \\
1.3 \\
9.0\end{array}$ \\
\hline 4 & $\begin{array}{ll} & 7.5 \mathrm{Cu} \\
15 & \mathrm{Cd} \\
75 & \mathrm{Zn}\end{array}$ & $\begin{array}{l}55 \\
58 \\
58\end{array}$ & $\begin{array}{l}10.6 \\
14.6 \\
79.4\end{array}$ & $\begin{array}{r}7.7-13.5 \\
12.5-17.6 \\
58.5-95.0\end{array}$ & $\begin{array}{r}1.5 \\
1.5 \\
10.6\end{array}$ \\
\hline 5 & $\begin{array}{rl}15 & \mathrm{Cu} \\
30 & \mathrm{Cd} \\
150 & \mathrm{Zn}\end{array}$ & $\begin{array}{l}56 \\
57 \\
57\end{array}$ & $\begin{array}{r}17.6 \\
29.5 \\
148.0\end{array}$ & $\begin{array}{c}14.2-21.0 \\
22.0-35.0 \\
107.0-176.0\end{array}$ & $\begin{array}{r}2.2 \\
3.1 \\
16.9\end{array}$ \\
\hline 6 & $\begin{array}{rl}30 & \mathrm{Cu} \\
60 & \mathrm{Cd} \\
300 & \mathrm{Zn}\end{array}$ & $\begin{array}{l}56 \\
57 \\
58\end{array}$ & $\begin{array}{r}32.0 \\
59.5 \\
302.8\end{array}$ & $\begin{array}{c}25.3-38.0 \\
47.5-69.0 \\
270.0-360.0\end{array}$ & $\begin{array}{r}3.8 \\
4.9 \\
29.3\end{array}$ \\
\hline
\end{tabular}

in 10 per cent acetic acid. All glassware was soaked in 10 per cent concentrated nitric acid and rinsed twice with deionized water. Metal toxicant concentrations were determined with a Perkin-Elmer* Model 303 atomic adsorption spectrophotometer and checked against reagent grade standards in 10 per cent acetic acid. The average extraction recoveries of 58 copper- and 56 cadmium-spiked sample determinations were 95.0 and 99.1 per cent, respectively. Zinc in the chronic tests and all three metals in the acute exposures were run directly on the spectrometer after acidification.

\footnotetext{
* Mention of commercial products does not constitute endorsement by the United States Environmental Protection Agency.
} 
Reported concentrations for all metals in all tests have been corrected for extraction recoveries or matrix and solvent effects, or both, where necessary.

The fathead minnows were collected on 30 June, 1968, as embryos from spring-fed ponds at the Newtown Fish Farm. They were hatched in laboratory holding tanks and maintained there until 20 July, 1968, when 40 fish were distributed to each of the six exposure chambers. The bioassay continued for 12.5 months until terminated 5 August of the succeeding year. Exposure chambers were constructed of glass, measured $30.5 \times 30.5 \times 91.5 \mathrm{~cm}$, and had a standpipe controlled water volume of about 601 . One-third of the tank volume was blocked off with stainless steel screen to provide an exposure area for larvae that was separated from the adults. This $930.5-\mathrm{cm}^{2}$ rearing area was divided into two equal compartments by a glass plate so that two groups of larvae could be tested simultaneously in each tank. Incoming water was delivered to the larval compartments, then flowed to the larger compartments and out the standpipes at the opposite ends of the tanks. Five tunnel-like sections of halved, $7.6-\mathrm{cm}$ ID cement and asbestos drain tile, each $7.6 \mathrm{~cm}$ long, were distributed in each tank to provide cover and spawning substrates.

Water temperature was monitored continuously by a 7-day recording thermometer. Weekly means during the bioassay ranged from $25^{\circ} \mathrm{C}$ during the summer months to $21^{\circ} \mathrm{C}$ during the winter. Weekly fluctuations were never more than $5^{\circ} \mathrm{C}$, and diel fluctuations averaged $1-2^{\circ} \mathrm{C}$. The maximum and minimum temperatures recorded were $27^{\circ}$ and $20^{\circ} \mathrm{C}$. Illumination was provided by cool-white fluorescent ceiling fixtures and a string of six 40-W incandescent lamps, with one positioned about $2 \mathrm{ft}$ above the middle of each tank. An automatic time switch controlled the photoperiod at $16 \mathrm{~h}$ of daylight through the bioassay.

Fish were fed a dry commercial trout food supplemented at least once a week with plankton collected from outdoor ponds or cultured in the laboratory. Periodic treatment with terramycin or neomycin (antibiotics), Dexon ${ }^{\circledR}$ (a fungicide), or $\mathrm{KMnO}_{4}$ (for external parasites) was necessary to maintain the health of the fish.

On 16 August, about 1 month after starting the exposure and 45 days of age, 25 fish were randomly selected from each tank to remain part of the test, and the rest were discarded. Before being returned to the exposure chamber they were anaesthetized with paraldehyde ( $2 \mathrm{ml} \mathrm{1}^{-1}$ of water), and their lengths were determined.

After the fish began to mature and started spawning, the number of males showing secondary sexual development was periodically reduced to five per tank, or one male to each tile substrate. As each male established a territory under a different tile, fighting was minimized and interference with spawning was probably reduced. Eggs were deposited on the underside of these substrates by the females and guarded there by the males until removed between noon and 2:00 p.m. that same day for counting. From several spawnings in each tank, 50 eggs were separated out for determining embryo viability, hatching success, and larval survival. These embryos were put back into the appropriate test tanks in gently oscillating incubation cups consisting of $7.6-\mathrm{cm}$ sections of $5.1-\mathrm{cm}$ o.d. polyethylene water hose with $40-$ mesh nylon screen covering the bottom end. To observe larval survival, duplicate groups of 50 eggs from a single spawning were kept and incubated. Cups were checked every day for dead eggs, which were removed and recorded, and the cup screens cleaned, if necessary. After hatching began, generally about 6 days after they were spawned, the cups were not disturbed until all larvae had hatched. The number of living larvae from the 
original 50 eggs was determined to obtain the percentage of successful hatch; the larvae were then either discarded or transferred to larval growth chambers for further study.

For the larval exposures, one of the two groups of recently hatched fish was put into each of the two larval compartments, designated $A$ and $B$. Only duplicate incubation groups experiencing 80 per cent or better hatchability were used. The $B$ group in each tank was fed finely ground dry food alone, the usual food provided in most previous chronic exposures; the $A$ group was fed the same amount of dry food plus a diet supplement of laboratory-reared plankton. The plankton cultures were not precisely controlled, but they usually contained mixtures of midge larvae, copepods, cladocerans, ostracods, rotifers, algae, diatoms and protozoans. The cultures were started according to the formula of BANTA (1921), maintained under constant light, and fed every day or two with a yeast suspension. Therefore, in addition to testing the sensitivity of larvae to the five toxicant concentrations, two differing feeding regimens were compared. All larval exposures lasted 1 month from the time the newly hatched fish were transferred from the embryo cups.

Acute mortality exposures were conducted with each of the metals singly and with the trimetal combination. The same sources of test fish and water were used for all the acute tests. Acclimation procedures for test fish were followed as recommended by the American Public Health Association (1965). All acute bioassays were conducted in proportional diluter, intermittent-flow systems, with test endpoints (lethal threshold concentrations) determined as described by EAToN (1970). Duplicate chambers were employed, each containing $10 \mathrm{fish}$, and temperatures were controlled at $23^{\circ}-25^{\circ} \mathrm{C}$.

\section{RESULTS}

Total length of parental fish at 45 days of age, or after 1 month of exposure, was greater on the average in the control tank than that of the fish in the test concentra-

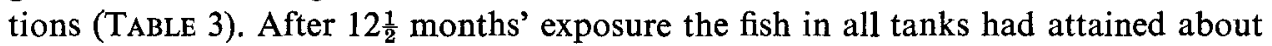
the same mean length. The mean terminal weight of both males and females was less in the highest concentration, however, than that in the other concentrations (TABLE 3). These fish were paler, and development of secondary sexual characteristics among the males was slowed or inhibited. For this reason no excess mature males were removed from the high concentration chamber during the test. In this tank the strong interactions between the males normally associated with spawning activities were absent.

One or two mortalities were suffered in most tanks after the fish were thinned at 45 days of age. (Mean survival before thinning was 69 per cent for all tanks and ranged from 65 to 80 per cent.) All the fish, except one in the high concentration tank, were apparently normal and healthy until a few hours before they died or were removed from the tanks because death was imminent. Visible symptoms of internal hemorrhage and loss of equilibrium were assumed to be caused by disease, not the toxicant. One of the fish that died in the high concentration, however, became increasingly deformed over a 142-day period before it succumbed, and this abnormality might have been toxicant related. A less severely crippled fish in this concentration lived until the end of the exposure.

The first few spawnings took place in late November and increased to a maximum 
TABLE 3. LENGTH AT 45 DAYs, MORTALITY, NUMBER OF MATURE MALES REMOVED DURING THE TEST, AND TERMINAL LENGTH, WEIGHT AND NUMBER OF PARENTAL FISH AT VARIOUS CONCENTRATIONS OF COPPER, CADMIUM AND ZINC

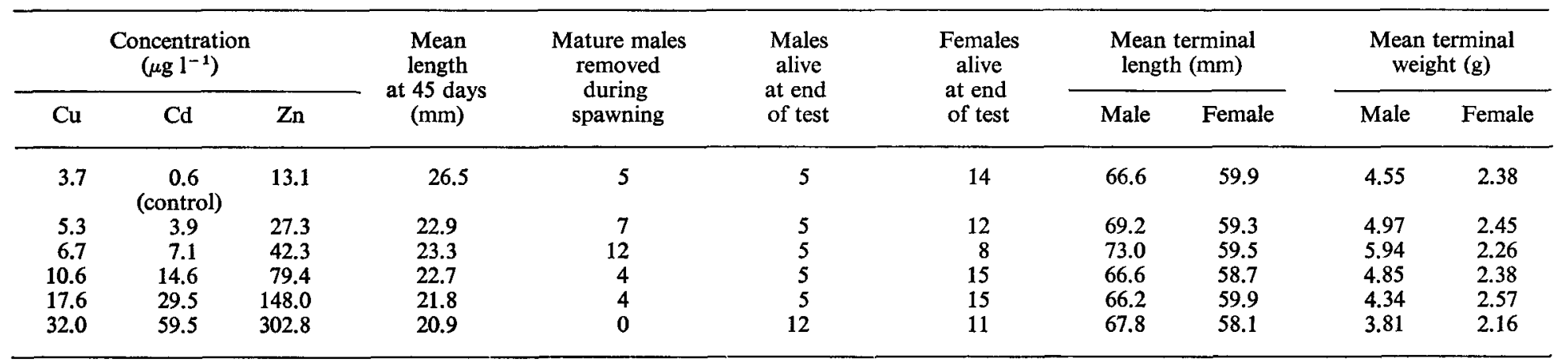


of 92 in all tanks during March. At the four higher toxicant concentrations, severe effects on reproductive performance were noticeable for most of the criteria used (TABLE 4). In the lowest concentration the number of spawnings per female and number of embryos per female (TABLE 4) were 22 and 30 per cent lower, respectively, than among the control fish. These differences might have been caused by the toxicant, but the effect must be judged as slight. In similar fathead minnow chronic tests employing duplicate exposure chambers (BRUngs, 1969; PICKering and Gast, 1972) variations of $20-40$ per cent have been observed between duplicates in these parameters. Spawning in all higher concentrations was greatly reduced (78 per cent or more) as compared to the control results.

Additional abnormalities were noticed in the two highest concentration tanks. In five of the 20 spawnings recorded for the second highest concentration, embryos were deposited on a substrate in the forenoon and an estimate of their number recorded, but they were eaten before they were to have been removed in the afternoon. Embryos from two of the three spawnings in the highest concentration were also eaten. Because this could have happened with additional spawnings that were not observed, or some of the embryos could already have been eaten from those that were recorded, the embryo numbers and spawning results at the higher concentrations should be considered approximations. Also, most groups of embryos removed from spawning tiles in the three highest concentrations were much more loosely attached than those from other concentrations, which would probably make them more available to be eaten. The 17 embryos of the one batch recovered from the highest concentration were opaque and infertile. Hatching success was essentially better in all concentrations than among the controls (TABLE 4). Six groups of 50 embryos from three different control spawnings that were immediately transferred into the high concentration hatched well also.

Growth and survival for about 30 days after hatching was observed for 23 groups of embryos from 12 different spawnings (TABLE 5). Observations were tabulated on the basis of exposure concentration, food regimen, and season when exposed. Season of exposure was the only recorded variable that seemed to be correlated with the wide variation in growth rate. Very significant growth-rate differences occurred between larvae fed food culture organisms plus dry food and those, from the same embryo batch, fed dry food alone. Toxicant concentration did not seem to effect growth of larvae, even in the two highest concentrations. The average test temperatures during the winter, spring and summer test periods were $22.2^{\circ}, 23.0^{\circ}$ and $24.2^{\circ} \mathrm{C}$, respectively, but these differences are not believed to account fully for the seasonal growth variations. Probably important also was the amount of food in the outdoor water supply reservoir where seasonal temperature fluctuations were much more pronounced.

None of the variables of diet and season, and consequently mean growth, or toxicant concentration seemed to have an effect on the number of larvae surviving for 30 days after hatch (TABLE 6). Mean percentage survival for all larvae exposed was 77.

The chronic bioassay was terminated on 5 September after a gradual decline in spawning rate. An average of 43 spawnings was recorded in July and August as compared to 74 month $^{-1}$ in April, May and June. Only one was recorded in the first 5 days of September.

Acute lethal threshold determinations were made on a $1: 2: 10$ concentration 


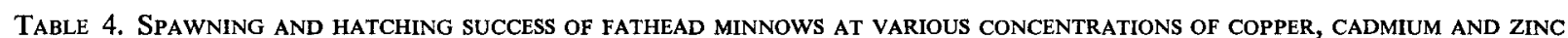

\begin{tabular}{|c|c|c|c|c|c|c|c|c|c|c|}
\hline \multicolumn{3}{|c|}{$\begin{array}{l}\text { Concentration } \\
\left(\mu \mathrm{g} \mathrm{I}^{-1}\right)\end{array}$} & \multirow{2}{*}{$\begin{array}{l}\text { Number } \\
\text { of females }\end{array}$} & \multirow{2}{*}{$\begin{array}{c}\text { Number of } \\
\text { spawnings }\end{array}$} & \multirow{2}{*}{$\begin{array}{l}\text { Number of } \\
\text { spawnings/ } \\
\text { female }\end{array}$} & \multirow{2}{*}{$\begin{array}{l}\text { Total } \\
\text { number of } \\
\text { embryos } \\
\text { produced }\end{array}$} & \multirow{2}{*}{$\begin{array}{l}\text { Number of } \\
\text { embryos/ } \\
\text { spawning }\end{array}$} & \multirow{2}{*}{$\begin{array}{l}\text { Number of } \\
\text { embryos/ } \\
\text { female }\end{array}$} & \multirow{2}{*}{$\begin{array}{c}\text { Number of } \\
\text { embryo groups } \\
\text { hatched } \\
\text { (50 embryos/ } \\
\text { group) }\end{array}$} & \multirow{2}{*}{$\begin{array}{c}\text { Embryos } \\
\text { hatching* } \\
(\%)\end{array}$} \\
\hline $\mathrm{Cu}$ & $\mathrm{Cd}$ & $\mathrm{Zn}$ & & & & & & & & \\
\hline 3.7 & $\begin{array}{c}0.6 \\
\text { (control) }\end{array}$ & 13.1 & 14 & 249 & 17.8 & 41,092 & 165 & 2935 & 88 & 79.4 \\
\hline 5.3 & 3.9 & 27.3 & 12 & 165 & 13.8 & 24,403 & 147 & 2034 & 52 & 78.4 \\
\hline 6.7 & 7.1 & 42.3 & 8 & 27 & 3.4 & 4058 & 150 & 507 & 11 & 91.8 \\
\hline 10.6 & 14.6 & 79.4 & 15 & 59 & 3.9 & 6224 & 105 & 415 & 16 & 92 \\
\hline 17.6 & 29.5 & 148.0 & 15 & 20 & 1.3 & 1785 & 89 & 119 & 9 & 86.8 \\
\hline 32.0 & 59.5 & 302.8 & 11 & 3 & 0.27 & 51 & 17 & 4.6 & $0 ;(6) \dagger$ & $(93.7)_{\ddagger}^{\ddagger}$ \\
\hline
\end{tabular}

* Over 95 per cent of mortality indicated here occurred before hatching.

$\dagger$ The six embryo groups (from three spawnings) in parentheses were transferred from the control tank on the day they were spawned.

$\ddagger$ Percentage hatch of the embryos transferred from the control tank. 
TABle 5. MEAN TERMINAL WEIGHT IN MILLIGRAMS OF FATHEAD MINNOW LARVAL GROUPS EXPOSED TO COPPER, CADMIUM AND ZINC FOR 30 DAYS AFTER HATCHING AND MAINTAINED ON DIFFERENT FEEDING REGIMENS (FOOD CULTURE PLUS DRY FOOD AND DRY FOOD ALONE) DURING THREE SEASONAL PERIODS

\begin{tabular}{|c|c|c|c|c|c|c|c|c|c|c|c|}
\hline \multirow{2}{*}{\multicolumn{3}{|c|}{$\begin{array}{l}\text { Concentration } \\
\left(\mu \mathrm{g} \mathrm{l}^{-1}\right)\end{array}$}} & \multicolumn{3}{|c|}{ Winter } & \multicolumn{3}{|c|}{ Spring } & \multicolumn{3}{|c|}{ Summer } \\
\hline & & & \multirow{2}{*}{$\begin{array}{c}\text { Duration } \\
\text { of } \\
\text { exposure }\end{array}$} & \multirow{2}{*}{$\begin{array}{l}\text { Food culture } \\
\text { plus dry } \\
\text { food }\end{array}$} & \multirow{2}{*}{$\begin{array}{l}\text { Dry } \\
\text { food } \\
\text { alone }\end{array}$} & \multirow{2}{*}{$\begin{array}{c}\text { Duration } \\
\text { of } \\
\text { exposure }\end{array}$} & \multirow{2}{*}{$\begin{array}{l}\text { Food culture } \\
\text { plus dry } \\
\text { food }\end{array}$} & \multirow{2}{*}{$\begin{array}{l}\text { Dry } \\
\text { food } \\
\text { alone }\end{array}$} & \multirow{2}{*}{$\begin{array}{c}\text { Duration } \\
\text { of } \\
\text { exposure }\end{array}$} & \multirow{2}{*}{$\begin{array}{l}\text { Food culture } \\
\text { plus dry } \\
\text { food }\end{array}$} & \multirow{2}{*}{$\begin{array}{l}\text { Dry } \\
\text { food } \\
\text { alone }\end{array}$} \\
\hline $\mathrm{Cu}$ & $\mathrm{Cd}$ & $\mathrm{Zn}$ & & & & & & & & & \\
\hline \multirow[t]{2}{*}{3.7} & $\begin{array}{c}0.6 \\
\text { (control) }\end{array}$ & 13.1 & $\begin{array}{l}1 / 4 \\
2 / 9\end{array}$ & 15 & 5 & $\begin{array}{l}3 / 25- \\
4 / 25\end{array}$ & 60 & 10 & $\begin{array}{l}7 / 26- \\
8 / 25\end{array}$ & 104 & 17 \\
\hline & & & $\begin{array}{l}2 / 9- \\
3 / 11\end{array}$ & 14 & 3 & & - & - & - & - & - \\
\hline 5.3 & 3.9 & 27.3 & $\begin{array}{l}1 / 20 \\
2 / 20\end{array}$ & 17 & $-^{*}$ & & - & - & $\begin{array}{l}8 / 9 \\
9 / 9\end{array}$ & 69 & 16 \\
\hline 6.7 & 7.1 & 42.3 & $\begin{array}{l}1 / 14 \\
2 / 13\end{array}$ & 20 & 4 & & - & - & $\begin{array}{l}7 / 16- \\
8 / 16\end{array}$ & 66 & 15 \\
\hline 10.6 & 14.6 & 79.4 & $\begin{array}{l}2 / 9- \\
3 / 11\end{array}$ & 30 & 7 & $\begin{array}{l}3 / 27- \\
4 / 26\end{array}$ & 44 & 11 & - & - & - \\
\hline 17.6 & 29.5 & 148.0 & $\begin{array}{l}1 / 22 \\
2 / 23\end{array}$ & 16 & 10 & & - & - & - & - & - \\
\hline 32.0 & 59.5 & 302.8 & & - & - & & - & - & $\begin{array}{l}7 / 27- \\
8 / 26\end{array}$ & 82 & 19 \\
\hline
\end{tabular}

* An adult fish jumped into this larval compartment; because all but one of the larvae disappeared before or soon after the adult was removed, the results were discarded. 


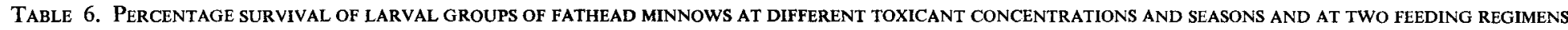

\begin{tabular}{|c|c|c|c|c|c|c|c|c|c|}
\hline & & & \multicolumn{2}{|c|}{$\begin{array}{l}\text { Winter } \\
1 / 4-3 / 11\end{array}$} & \multicolumn{2}{|c|}{$\underset{3 / 25-4 / 26}{\text { Spring }}$} & \multicolumn{2}{|c|}{$\begin{array}{l}\text { Summer } \\
7 / 16-9 / 9\end{array}$} & \multirow[b]{3}{*}{ Mean } \\
\hline \multicolumn{3}{|c|}{$\begin{array}{l}\text { Concentration } \\
\left(\mu \mathrm{g} \mathrm{l}^{-1}\right)\end{array}$} & \multirow{2}{*}{$\begin{array}{l}\text { Food culture } \\
\text { plus dry } \\
\text { food }\end{array}$} & \multirow{2}{*}{$\begin{array}{l}\text { Dry } \\
\text { food } \\
\text { alone }\end{array}$} & \multirow{2}{*}{$\begin{array}{l}\text { Food culture } \\
\text { plus dry } \\
\text { food }\end{array}$} & \multirow{2}{*}{$\begin{array}{l}\text { Dry } \\
\text { food } \\
\text { alone }\end{array}$} & \multirow{2}{*}{$\begin{array}{l}\text { Food culture } \\
\text { plus dry } \\
\text { food }\end{array}$} & \multirow{2}{*}{$\begin{array}{l}\text { Dry } \\
\text { food } \\
\text { alone }\end{array}$} & \\
\hline $\mathrm{Cu}$ & $\mathrm{Cd}$ & $\mathrm{Zn}_{\mathbf{n}}$ & & & & & & & \\
\hline \multirow[t]{2}{*}{3.7} & 0.6 & 13.1 & 36 & 61 & 54 & 86 & 66 & 54 & \\
\hline & (control) & & 80 & 81 & - & - & - & - & 66 \\
\hline 5.3 & 3.9 & 27.3 & 54 & - & - & - & 84 & 86 & 75 \\
\hline 6.7 & 7.1 & 42.3 & 94 & 82 & 一 & - & 84 & 90 & 87 \\
\hline 10.6 & 14.6 & 79.4 & 68 & 72 & 90 & 98 & - & - & 82 \\
\hline 17.6 & 29.5 & 148.0 & 90 & 58 & - & - & - & - & 74 \\
\hline \multirow[t]{2}{*}{32.0} & 59.5 & 302.8 & - & - & - & - & 80 & 78 & 79 \\
\hline & & Mean & 70 & 71 & 72 & 92 & 79 & 77 & 77 \\
\hline
\end{tabular}


mixture of copper, cadmium and zinc (the same ratio as in the chronic exposure) and on zinc alone. The bioassay values obtained after combining the results from the duplicate exposures were $154 \mu \mathrm{g}^{-1}$ copper, $320 \mu \mathrm{g}^{-1}$ cadmium, and $2050 \mu \mathrm{g}^{-1}$ zinc for the mixture, and $5030 \mu \mathrm{g}^{-1}$ for zinc alone. The duration of the two tests was 72 and $96 \mathrm{~h}$, respectively, and the results are based on analyses of samples composited over a 4-day period for the mixture and individual daily measurements for the zinc.

\section{DISCUSSION}

When the trimetal chronic exposure results are examined, toxicant effects are apparent even in the lowest concentration. It is possible to determine whether or not the metals in the mixture were additive in their effects because each of them has one or more specific and identifiable toxic actions. For example, zinc reduces the number of embryos produced per female in proportion to its concentration even though the adult fish appear to develop normally (BRUNGS, 1969). This is different from the effect of copper on spawning because it occurs over a very wide rather than a narrow range of toxicant concentrations. If the number of embryos produced per female at the various zinc concentrations of the trimetal test is plotted along with the same data from the test conducted by Brungs (1969) with zinc only (FIG. 1), the values

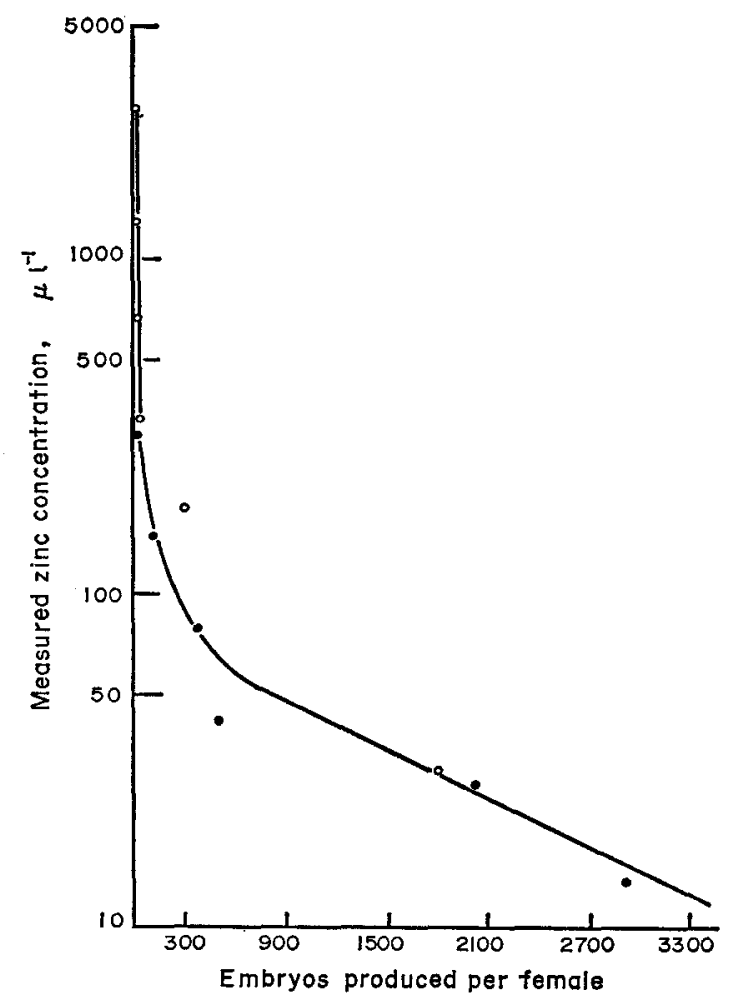

Fig. 1. Number of embryos produced per female fathead minnow in chronic bioassays with zinc alone, (O) (BRUNGS, 1969) and with the trimetal mixture, (O) reported here. (The numbers of embryos per female values have been adjusted so that they correspond to spawning periods of equal duration for the two exposures; actual duration was 225 days for the zinc test and W.R. $7 / 11-0$ 263 days for the trimetal test.) 
reinforce one another, and a single line serves both sets reasonably well. It can be concluded, therefore, that the chronic toxicity of the trimetal mixture was little if any more toxic than its zinc component alone.

The tendency for embryos to be loosely stuck to spawning tiles at the highest test concentrations which was observed in this study, was also observed by BRUNGS (personal communication) in the zinc chronic test, but he removed embryos from tiles upon completion of spawning rather than, as here, collecting them at about the same time each day. This might help explain the slightly lower numbers of embryos at the three highest concentrations in this study as compared to corresponding concentrations in the zinc chronic test. Brung's procedure probably allowed less of an opportunity for fish to eat embryos that were loosely attached to the tiles.

In the chronic bioassay conducted by MounT (1968), no eggs were obtained from fish that had been exposed to $33 \mu \mathrm{g}^{-1}$ of copper for several months. However, in a more recent copper chronic test conducted by BRUngs, Pickering and StePhan (unpublished data) a small number of spawnings was recorded among fish exposed to $100 \mu \mathrm{g}^{-1}$ of copper. In both copper chronic tests, fish exposed to the highest concentrations of 95 and $100 \mu \mathrm{g}^{-1}$, respectively, were smaller, and development of secondary sexual characteristics was inhibited at $95 \mu \mathrm{g}^{-1}$ in the study conducted by MounT (1968). At the highest concentration in the trimetal chronic test containing $32 \mu \mathrm{g}^{-1}$ of copper, spawning was greatly reduced, the fish were smaller, and sexual development was inhibited. As most of the reduced spawning can be assumed to have been caused by zinc, the other two effects attributable to copper indicate an enhancement of its toxicity in the trimetal mixture because they occurred at a lower concentration than in the single toxicant tests. However, differences in the levels of susceptibility of test fish might also help account for apparent enhancement or reduction in toxicity of the mixture.

In the second of two cadmium chronic bioassays, PICKERING and GaST (1972) observed a small (18 per cent) but significant $(P=0.05)$ reduction in hatching success among four groups of control eggs exposed to $57 \mu \mathrm{g}^{-1}$ of cadmium, as compared to control eggs left in the control chamber. No other toxic effects were seen at $57 \mu \mathrm{g} \mathrm{1^{-1 }}$ or below, but several mortalities occurred at $110 \mu \mathrm{g} 1^{-1}$. In the trimetal study six groups of control eggs were transferred into the high concentration tank containing $59 \mu \mathrm{g}^{-1}$ of cadmium, but hatchability was actually better than among eggs hatched in the control tank ( 93.7 vs. 79.4 per cent). A smaller number of eggs was tested in $59 \mu \mathrm{g}^{-1}$, however. Here it would seem that the specific toxic action in the trimetal exposure was reduced.

It can be concluded, then, that the toxicity of the trimetal mixture could not have been predicted closely from the results of the single-toxicant chronic tests by assuming they were totally additive in their toxic effects. All previous metal- or other pollutantmixture exposures with fish have employed acute (short-term) bioassays, and, in general, they have demonstrated some degree of positive interaction. LLoYd (1961) found that the toxicities of copper and zinc were additive in acute threshold mortality tests (4- to 7-day duration) in both hard and soft water. Summation of proportions of acute threshold levels has been demonstrated for unionized ammonia with monohydric phenols (HERBERT, 1962); for ammonia with zinc (Herbert and SHURBEN, 1964); and for copper with ammonia and for zinc with phenol (HERBERT and VANDYKE 1964). SPRAGUE and RAMSEY (1965) observed summation of copper and zinc toxicity 
to Atlantic salmon in soft water. Means of predicting the toxicities of mixtures of three substances, based on 48-h LC50 determinations and assuming direct summation, have been described by BROWN (1968), BRown et al. (1969), and BROWN and DALTON (1970). Their 48-h LC50 values are thought to provide a "reasonable estimate" of acute threshold concentrations.

Acute test values were determined for copper, cadmium and zinc, both singly and in a mixture with their concentrations in about the same ratio as in the chronic bioassay (TABLE 7). Because it took considerably less of each metal in combination

TABLE 7. Results OF ACUTE TOXICITY DETERMinATIONS WITH A MIXTURE OF COPPER, CADMIUM AND ZINC, IN ABOUT THE SAME RATIO OF CONCENTRATIONS AS IN THE MIXTURE CHRONIC, AND WHEN TESTED SINGLY

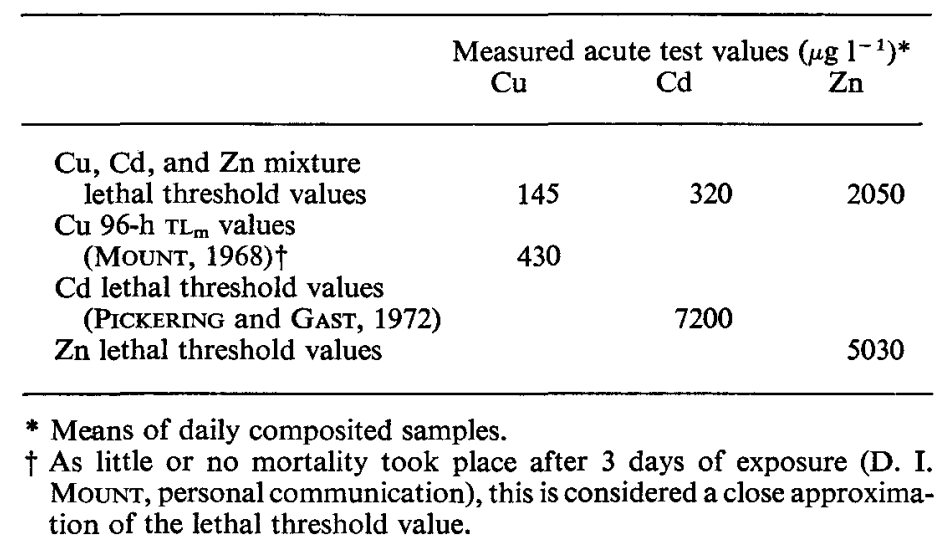

to obtain a threshold value, it is apparent that some toxicity-increasing interaction occurred. The metal concentrations in the mixture were 36,4 and 41 per cent of the individual-test copper, cadmium and zinc threshold values, or a sum total of 81 per cent. Because the total should equal 100 per cent under the assumption that the proportions were directly additive in acute effect, the results indicate that their summation was somewhat enhanced (i.e. it took less of them in combination to reach a lethal threshold concentration than would have been expected). In general, however, the acute test results here agree with the findings of the investigations described previously.

Some instances have also been reported of smaller proportions of the acutely toxic concentrations of these substances not adding up (i.e. more than the expected amounts were required to reach a lethal threshold concentration). EDWARDS and BRowN (1966) observed less than the expected toxicity in a mixture of phenol, zinc and ammonia in which the predicted contributions were to have been 10, 80 and 10 per cent, respectively. LLOYD and ORR (1969) infer that either or both of the proportions of phenol and ammonia were not included in the toxicity summation because of their small proportions. One of the bases for this suggestion is the results of a study in which they found evidence that ammonia at concentrations below 12 per cent of the lethal threshold level exerted no toxic action. This concept of a minimum concentration level, at about 10 per cent of the lethal threshold, below which straightforward summation should not be expected to occur, is in general agreement with the results of the fathead minnow trimetal chronic exposure. [Even the highest concentrations of copper, 
cadmium and zinc in the trimetal chronic test (32, 59 and $303 \mu \mathrm{g} \mathrm{1}^{-1}$, respectively) were less than 10 per cent of the individual lethal threshold values $(430,7200$ and $5030 \mu \mathrm{g} \mathrm{1}^{-1}$, respectively).] A clear exception, however, to this minimum concentration idea is provided in the study by SPRAGUE, ELSON and SAUNDERS (1965) of copper and zinc toxicity to Atlantic salmon parr. They found that copper and zinc in a mixture of concentrations equal to 1 per cent of their individual lethal thresholds were more than additive in causing avoidance.

Acknowledgements-The author wishes especially to thank Mr. W. HaUCKE for conducting most of the toxicant analyses; Mr. J. DRYER for routine analyses of testwater characteristics and calculation of means and standard deviations; and Mr. C. Stephen, Mr. Q. Pickering, Dr. W. A. Brungs, and Dr. D. MouNT for assistance in conducting various phases of the bioassays and criticism of the manuscript. Appreciation is also expressed to other members of the National Water Quality Laboratory and individuals who reviewed the manuscript.

\section{REFERENCES}

American Publch Health Association (1965) Standard Methods for the Examination of Water and Wastewater, 12th edn, 769 pp. New York.

Banta A. M. (1921) A convenient culture medium for daphnids. Science 53, 557-558.

BRown V. M. (1968) The calculation of the acute toxicity of mixtures of poisons to rainbow trout. Water Research 2, 723-733.

Brown V. M. and Dalton R. A. (1970) The acute lethal toxicity to rainbow trout of mixtures of copper, phenol, zinc and nickel. J. Fish. Biol. 2, 211-216.

Brown V. M., Jordan D. H. M. and Tiller B. A. (1969) The acute toxicity to rainbow trout of fluctuating concentrations and mixtures of ammonia, phenol and zinc. J. Fish. Biol. 1, 1-9.

Brungs W. A. (1969) Chronic toxicity of zinc to the fathead minnow, Pimephales promelas Rafinesque. Trans. Amer. Fish. Soc. 98, 272-279.

EAToN J. G. (1970) Chronic malathion toxicity to the bluegill (Lepomis macrochirus Rafinesque). Water Research 4, 673-684.

Edwards R. W. and Brown V. M. (1966) Pollution and fisheries: a progress report. Water Pollut. Control, London 66, 63-78.

Herbert D. W. M. (1962) The toxicity to rainbow trout of spent still liquors from the distillation of coal. Ann. appl. Biol. 50, 755-777.

Herbert D. W. M. and Shurben D. S. (1964) The toxicity to fish of mixtures of poisons. Ann. appl. Biol. 53, 33-41.

Herbert D. W. M. and VAN Dyke J. M. (1964) The toxicity to fish of mixtures of poisons-II. Copper-ammonia and zinc-phenol mixtures. Ann. appl. Biol. 53, 415-421.

LLOYD R. (1961) The toxicity of mixtures of zinc and copper sulphates to rainbow trout (Salmo gairdnerii Richardson). Ann. appl. Biol. 49, 535-538.

LLOYD R. and ORR L. D. (1969) The diuretic response by rainbow trout to sub-lethal concentrations of ammonia. Water Research 3, 335-344.

Mount D. I. (1968) Chronic toxicity of copper to fathead minnows (Pimephales promelas, Rafinesque). Water Research 2, 215-223.

Mount D. I. and BRungs W. A. (1967) A simplified dosing apparatus for fish toxicology studies. Water Research 1, 21-29.

Pickering Q. H. and Gast M. H. (1972) Acute and chronic toxicity of cadmium to the fathead minnow (Pimephales promelas, Rafinesque). J. Fish. Res. Bd Can. 29, 1099-1106.

Sprague J. B., Elson P. F. and SAUNDERS R. L. (1965) Sublethal copper-zinc pollution in a salmon river-a field and laboratory study. Int. J. Air Water Pollut. 9, 531-543.

Sprague J. B. and Ramsay B. ANN (1965) Lethal levels of mixed copper-zinc solutions for juvenile salmon. J. Fish. Res. Bd. Can. 22, 425-432.

STARY J. (1964) The Solvent Extraction of Metal Chelates 240 pp. Macmillan, New York. 